Revista de la red interuniversitaria de estudios sobre las literaturas rioplatenses contemporáneas en Francia

$8 \mid 2013$

Argentina y Uruguay: lecturas del país vecino en la literatura rioplatense contemporánea (siglos XX y XXI)

\title{
Travesías literarias entre dos orillas
}

\section{Marta Inés Waldegaray}

\section{OpenEdition}

\section{Journals}

Edición electrónica

URL: http://journals.openedition.org/lirico/1033

DOI: $10.4000 /$ lirico. 1033

ISSN: 2262-8339

Editor

Réseau interuniversitaire d'étude des littératures contemporaines du Río de la Plata

Referencia electrónica

Marta Inés Waldegaray, «Travesías literarias entre dos orillas », Cuadernos LIRICO [En línea], 8 | 2013,

Publicado el 01 enero 2013, consultado el 21 septiembre 2020. URL : http://journals.openedition.org/ lirico/1033 ; DOI : https://doi.org/10.4000/lirico.1033

Este documento fue generado automáticamente el 21 septiembre 2020

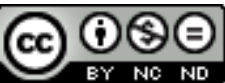

Cuadernos LIRICO está distribuido bajo una Licencia Creative Commons Atribución-NoComercialSinDerivar 4.0 Internacional 


\title{
Travesías literarias entre dos orillas
}

\author{
Marta Inés Waldegaray
}

1 Países hermanos y también países vecinos, la relación histórica entre la República Argentina y la República Oriental del Uruguay ha sido, desde sus orígenes coloniales, pasando por las luchas independentistas, hasta hoy, estrecha. Más estrecho y cercano es aún el vínculo entre sus ciudades capitales. Buenos Aires y Montevideo son los polos de atracción de una unidad geográfica y cultural constituida por las dos orillas que limitan el Río de la Plata. Corta es la distancia que las separa y sus diferencias culturales y geográficas, casi imperceptibles.

2 Nuestra historia literaria da cuenta de esta unidad. La denominación «literatura rioplatense » circuló de manera dominante hasta finales del siglo XIX, momento en el cual comenzó a preferirse una denominación distintiva para la producción literaria de cada orilla. Las expresiones « literatura argentina » $\mathrm{y}$ « literatura uruguaya » disuelven la unidad cultural y resaltan la diferencia nacional.

3 Independientemente de las denominaciones estipuladas, aunque sin minimizar los implícitos ideológicos que ellas suponen, este número de Cuadernos LIRICO pretende interrogar las lecturas que los escritores argentinos y uruguayos contemporáneos han realizado y vienen realizando de esta cercana distancia. Entendemos por lecturas el amplio espectro de la producción literaria ficcional, ensayística y crítica que liga a ambas orillas. Los trabajos reunidos en el presente volumen se interesan por el diálogo literario entablado desde uno y otro lado y se sitúan temporalmente dentro del marco del siglo XX y lo que va del XXI. Una encuesta realizada a seis escritores rioplatenses relacionados profesional y/o biográficamente con la región (los argentinos Carlos María Domínguez, Sergio Chejfec y Hernán Ronsino ; los uruguayos Fernanda Trías, Alicia Migdal y Juan Carlos Mondragón) cierra el volumen.

4 La presente introducción intentará recorrer los núcleos textuales que sentaron las bases del proyecto. El objetivo que nos guía en estas líneas no es el de la exhaustividad histórica ni textual, sino el de presentar algunos mojones literarios así como ciertas reflexiones críticas que han orientado la reflexión en torno al tema. Se trata de un amplio panorama que se extiende desde el imaginario de la conquista del Río de la Plata hasta nuestra literatura contemporánea pasando por la literatura romántica colonial. 


\section{«El olor matricial de ese río desmesurado » 1}

La colonización en el Río de la Plata fue la amarga historia de una ilusión tronchada. Ni metales preciosos, ni civilizaciones maravillosas, ni deslumbrantes ciudades, la llanura sin límites que el ancho estuario rioplatense ofrecía a las primeras expediciones españolas nada tenía de la Tenochtitlán azteca ni del Cuzco imperial incaico. Apenas algunas tribus dispersas, más o menos nómades. Pesadilla, desencanto, hambre, cautiverio, naufragios, incendios, indígenas belicosos, cuando no antropófagos, las crónicas y relatos sobre la fundación de lo que con optimismo pretendió ser Santa María del Buen Ayre están marcados por la desesperación y ponen en jaque las versiones más triunfalistas del descubrimiento. De estas «miserias e infortunios » brinda testimonio Ruy Díaz de Guzmán en su Anales del descubrimiento, población y conquista de las Provincias del Río de la Plata (conocida como la Argentina manuscrita) terminada de escribir en 1612 y publicada por primera vez en 1835 con el título Historia del descubrimiento, población y conquista de las provincias del Río de la Plata. Al comentar las adversidades vividas en la región, Guzmán reflexiona diciendo que en la conquista del Río de la Plata aquellos españoles « pensaron salir muchos ricos y aprovechados, y fue tan al contrario, que no ha habido alguno que hubiese vuelto remediado a su patria, antes acabaron los más de ellos sus vidas miserablemente. $»^{2}$ Acaso el origen de tantos males se debiera a aquel viajero de la malograda expedición de Pedro de Mendoza (1535-1536) que habría comido el cuerpo de su hermano muerto el día de Corpus Christi del año 1535, según el relato testimonial que de aquella empresa y que de aquel acto dejó el alemán Ulrich Schmidel :

Sucedió que tres españoles habían hurtado un caballo y se lo comieron a escondidas; y esto se supo; así se los prendió y se los dio tormento para que confesaran tal hecho; así fue pronunciada la sentencia que a los tres susodichos españoles se los condenara y ajusticiara y se los colgara en una horca. Así se cumplió esto y se los colgó en una horca. Ni bien se los había ajusticiado y cada cual se fue a su casa y se hizo noche, aconteció en la misma noche por parte de otros españoles que ellos han cortado los muslos y los pedazos de carne del cuerpo y los han llevado a su alojamiento y comido. También ha ocurrido entonces que un español se ha comido su propio hermano que estaba muerto. Esto ha sucedido en el año de 1535 en nuestro día de Corpus Cristi en la sobredicha ciudad de Buenos Aires. ${ }^{3}$

6 Las imágenes pertenecientes a la serie de Grandes Viajes correspondientes a la Serie América del grabador y editor liejense Theodore de Bry ilustran la segunda edición alemana (1597) de la obra de Schmidl y reproducen la conquista del Río de la Plata como una epopeya cruel.

7 La antropofagia es la marca de origen de la mítica y malograda fundación de Buenos Aires. Así lo recuerdan los célebres versos de Jorge Luis Borges :

$¿$ Y fue por este río de sueñera y de barro que las proas vinieron a fundarme la patria?

Irían a los tumbos los barquitos pintados

entre los camalotes de la corriente zaina.

Pensando bien la cosa, supondremos que el río era azulejo entonces como oriundo del cielo con su estrellita roja para marcar el sitio en que ayunó Juan Díaz y los indios comieron. 
« Fundación mítica de Buenos Aires », Cuaderno San Martín, $1929^{4}$

8 y también el desdichado grumete protagonista de El entenado de Juan José Saer: «Tierra, cielo vacío, carne degradada y delirio, con el sol arriba, pasando, desdeñoso y periódico, por los siglos de los siglos : así se presentaba ante mis ojos recién nacidos, esta mañana, la realidad. $»^{5}$. Único sobreviviente de la expedición española (históricamente, la expedición de Juan Díaz de Solís) que descubre el Río que recibiría el nombre de "Mar Dulce ", el personaje de Saer escribe sus memorias en España, ya viejo. Al remontar el Río, la expedición es atacada por los aborígenes de la tribu Colastiné. El adolescente permanecerá diez años en las costas del Mar Dulce, cautivo por nativos que practican rituales antropofágicos, orgías e incesto. Todo en esas tierras resulta primitivo y primigenio : «El olor de esos ríos es sin par sobre esta tierra. Es un olor a origen, a formación húmeda y trabajosa, a crecimiento. $»^{7}$.

Ocho años después, un pasaje de El río sin orillas (1991) parece expandir la escena del recuerdo de aquella revelación de la realidad consistente en la manifestación de un sentido (un destino, una pertenencia) y de una desilusión: la del peligro que entraña remontar el Río hacia su origen. En uno de los viajes de visita a la Argentina que Juan José Saer cuenta haber reiterado a partir de 1982, decide visitar la costanera norte y hacia allí se dirige en taxi. Frente al Río experimenta, como en la ficción su grumete, la realidad simbólica de la geografía rioplatense. Percibe en la circularidad de ambos horizontes que el contorno del Río de la Plata invita a ser remontado hacia el epicentro de la llanura. Con agudeza e ingenio, Saer describe e interpreta de esta manera dos imágenes que del paisaje rioplatense se imponen a su contemplación desde un mirador estratégicamente ubicado frente al Aeroparque. Allí instalado, el estuario del Plata se le revela como la figuración sexuada de un cangrejo y como la entrada infernal en el útero de la madre tierra. Dice entonces, refiriéndose a la forma del estuario del Río de la Plata:

$\mathrm{Su}$ forma verdadera, como tantas otras cosas en este mundo, difiere de su apariencia empírica y, tal como podemos verificarlo en cualquier mapa, se avecina mucho a la del escorpión, con la bahía de Samborombón (el nombre más rotundamente sonoro que conozco), y la bahía de Montevideo que forman las pinzas, y el último tramo del río Uruguay formando la cola. Si muchos viajeros que en estas tierras encontraron, para decirlo con un eufemismo, destino particularmente Juan Díaz de Solís, su descubridor, el más terrible de todos-, hubiesen tenido alguna idea de la forma que dormitaba en los confines del océano Atlántico, tal vez no se hubiesen aventurado con tanta desenvoltura por esta región desconocida, para ponerse a la merced de tan decididas tenazas. Pero podemos invertir el dibujo, interpretándolo esta vez en el sentido sureste-noroeste, y entonces aparece con claridad la silueta de un pene, con las dos bahías serviciales ya mencionadas figurando sin error posible los testículos, penetrando hacia el interior de la tierra, de la que la provincia de Entre Ríos contendría el útero, el vértice del delta el clítoris, y sus islas y la costa uruguaya respectivamente los labios grande y pequeño, en tanto que los ríos, riachos y arroyos, que se entrelazan al infinito en las inmediaciones y las líneas rojas de las redes viales y ferroviarias, las venas y las arterias que irrigan, viniendo del corazón y de los pulmones exhaustos de América del Sur -el Mato Grosso-, todo el sistema. Gaia, la Tierra, nacida inmediatamente después del Caos y, sobre todo, antes que Eros, dejándose penetrar, como antes por Pontos, el mar masculino, su propio hijo, por Poseidón, para engendrar al gigante Anteo, que obligaba a los viajeros que pasaban por Utica a luchar contra él y después de exterminarlos ornaba con sus despojos el santuario de su padre. ${ }^{8}$ 
Vientre devorador, descenso al infierno: el sentido que de este territorio la literatura rioplatense contemporánea ofrece en sus textos persiste en su simbología peligrosa y funesta.

11 En la primera mitad del siglo XIX, para el romanticismo rioplatense correspondiente al periodo rosista (1829-1852), el Río de la Plata significó la vía del camino al exilio, el paso a la otra orilla. Ambientada en la Buenos Aires rosista de 1840, Amalia ${ }^{9}(1851$ / 1855), de José Mármol, considerada como la primera novela rioplatense, retrata la realidad histórica del periodo en clave de novela romántica. La novela se inicia con el intento frustrado del joven unitario Eduardo Belgrano de cruzar el Río de la Plata para llegar a Montevideo e incorporarse allí al grupo de resistentes que luchan, desde el exilio, contra Rosas por la caída del régimen. Eduardo y sus amigos son traicionados y son interceptados por una partida rosista cuando están por embarcarse. Eduardo resulta herido y es conducido por su amigo Daniel Bello a la casa de su prima Amalia. Así nace el romance de ambos protagonistas en las primeras páginas de la novela. Casados, ambos intentan nuevamente el camino del exilio, pero en la víspera de la huida son descubiertos por una comisión de la Mazorca que los asesina. La otra orilla del Río de la Plata representaba en aquellos años la libertad y era el destino preferido del exilio romántico. Como bien se ocupa Mármol en precisar, en 1840, "en todo corazón argentino ", la bella ciudad de Montevideo significaba :

el contraste vivo y palpitante de la ciudad de Buenos Aires, en su libertad y en su progreso; y más que esto todavía, Montevideo despertaba en todo corazón argentino que llegaba a sus playas el recuerdo de una emigración refugiada en él por el espacio de once años, y la perspectiva de todas las esperanzas sobre la libertad argentina, que de allí surgían, fomentadas por la acción incansable de los emigrados, y por los acontecimientos que fermentaban continuamente en ese laboratorio vasto y prolijo de oposición a Rosas, en ese Montevideo en donde sólo con dejar hacer, la población se había triplicado en pocos años, desenvuéltose en espíritu de comercio y de empresas sorprendente, y amontonándose cuanto elemento parecía suficiente para dar en tierra con la vecina dictadura. ${ }^{10}$

12 Tierra de marcado contraste político (de exilio, de libertad), pero también de promisorios emprendimientos comerciales que contrastan con el modelo agropecuario del lado occidental del Plata, Montevideo brinda la (ilusión de) seguridad necesaria para planear la resistencia política y permite proyectar el retorno a la patria. El imaginario de la otra orilla engendrado desde la ciudad porteña tuvo en la vida cultural y en la literatura argentina del siglo XIX un significado político primordial. El Río fue para esta generación, emblema de soledad, de tristeza, de destierro. Nuevamente, Mármol :

Los que alguna vez hayan tenido la fantasía de pasearse en una noche oscura a las orillas del Río de la Plata, en lo que se llama el Bajo en Buenos Aires, habrán podido conocer todo lo que ese paraje tiene de triste, de melancólico, y de imponente al mismo tiempo. La mirada se sumerge en la extensión que ocupa el río, y apenas puede divisar a la distancia la incierta luz de alguno que otro buque de la rada interior. La ciudad, a dos o tres cuadras de la orilla, se descubre informe, oscura, inmensa. Ningún ruido humano se percibe, y sólo el rumor monótono y salvaje de las olas anima lúgubremente aquel centro de soledad y de tristeza.

Pero aquellos que hayan llegado a ese paraje, entre las sombras de la noche, para huir de la patria cuando el desenfreno de la dictadura arrojó a la proscripción centenares de buenos ciudadanos, ésos solamente podrán darse cuenta de las impresiones que inspiraba ese lugar, y en esas horas, en que se debía morir al puñal de la Mazorca si eran sentidos ; o decir jadiós !, a la patria, a la familia, al amor, si la 
fortuna les hacía pisar el débil barco que debía conducirlos a una tierra extraña, en busca de un poco de aire libre, y de un fusil en los ejércitos que operaban contra la dictadura. ${ }^{11}$

A finales del siglo XIX, el otro lado del Plata inspiraba en William Henry Hudson otra marcada diferencia en relación con el paradigma cultural dominante. Se trata de la admiración por lo bárbaro que despierta la silvestre y deliciosa ${ }^{12}$ tierra oriental. En un pasaje de La tierra purpúrea (1885), Hudson reflexiona acerca de los alcances de la civilización y, no sin cierta ambivalencia en cuanto a su grupo de pertenencia, expresa su deseo para la tierra oriental :

No es una característica exclusivamente británica el mirar a las gentes de otras nacionalidades con una cierta dosis de desprecio, pero es posible que entre nosotros ese sentimiento sea más fuerte que en otros pueblos, o, por lo menos, que se le exprese con menor reserva. [...] Permítaseme, en fin, despojarme de esos viejos anteojos ingleses, con montura de madera y lentes de cuerno para enterrarlos en este monte [...] y allí donde unos pocos meses antes yo cantaba los elogios de la civilización británica lamentando que ella sólo hubiera sido implantada aquí [...] Después de mis vagabundeos por el interior del país [...] no puedo decir que mantenga ahora aquella opinión. No puedo creer que si este país hubiera sido conquistado y recolonizado por Inglaterra, y si cuanto en él está torcido hubiera sido enderezado de acuerdo con nuestras ideas, mi relación con la gente hubiera tenido el aroma silvestre y delicioso que encontré en ella. Y si ese aroma característico no pudiera poseerse al mismo tiempo que la prosperidad material resultante de la energía anglosajona, yo expresaría el deseo de que esta tierra nunca conozca tal prosperidad. ${ }^{13}$

En 1941, Borges prologa La tierra purpúrea y celebra este corrimiento orientalista de Hudson. « Nacido en la provincia de Buenos Aires -escribe Borges-, en el círculo mágico de la pampa, [Hudson] elige sin embargo la tierra cárdena, donde la montonera fatigó sus primeras y últimas lanzas : el Estado Oriental. $»^{14}$ Borges parece rescatar la epopeya bárbara y su resistencia final. Considera que la novela de Hudson es superior a textos más canónicos de la literatura rioplatense como el Martín Fierro $(1872,1879)$ de José Hernández y Don Segundo Sombra (1926) de Ricardo Güiraldes.

En la última década del siglo XX, la literatura argentina vuelve sobre este motivo del cruce al Uruguay. Nos referiremos esquemáticamente a cinco novelas en las cuales se produce el cruce : El aire de Sergio Chejfec, El Dock de Matilde Sánchez, Los Cautivos. El exilio de Echeverría de Martín Kohan, Boomerang de Elvio Gandolfo y Plata quemada de Ricardo Piglia. ${ }^{15}$

El aire (1992) ${ }^{16}$, tercera novela de Sergio Chejfec, cuenta la historia de una decisión imposible de tomar, una decisión en estado de suspensión. Un hombre, Barroso, es abandonado por su mujer, Benavente. Antes de partir, ella le deja una breve nota en la cual le anuncia que decidió irse a Carmelo. Luego le enviará otra, anunciándole que se iría a Montevideo. No explica las causas que motivaron su decisión. Durante todo el relato, Barroso (personaje caracterizado por su pesadez existencial, su opacidad, su indolencia $)^{17}$ es incapaz de tomar la decisión de partir en busca de su mujer. Ni siquiera logra pasar a la otra orilla cuando, en el Tigre, ya está subido a una lancha que le permitiría cruzar el Río hacia Colonia ( en el instante preciso cuando la lancha se separaba del muelle, Barroso decidió no viajar, volver -aunque aún no se hubiera ido- a Buenos Aires $)^{18}$. Los canales del Tigre, preludios del paso al Río, son "una escenografía inmóvil $»^{19}$ en el espacio y en el tiempo ${ }^{20}$. La pesadumbre del narrador protagonista es el correlato subjetivo de una Buenos Aires empobrecida y en proceso de 
extinción, una ciudad anestesiada marcada por la desocupación y la partida de sus habitantes. "Ominosa $»^{21}$, siempre. Buenos Aires se vacía, se desertiza, se «pampeaniza » como dice el texto. Los baldíos avanzan sobre la urbe porteña : « Donde habían vivido amigos y familiares ahora quedaban los árboles y alguna que otra pared. De manera literal, el campo avanzaba sobre Buenos Aires. ${ }^{22}$. Quizás, Benavente haya dejado no solamente a Barroso, sino también la barbarie porteña, por el « exotismo leve y habitual ${ }^{23}$ del borde oriental del Río.

El Dock (1993) ${ }^{24}$ de Matilde Sánchez elige el Uruguay como tierra de encuentro y recomposición familiar. La protagonista femenina (narradora también, cuyo nombre desconocemos) emprende un viaje a la costa uruguaya, a Solís más precisamente, en compañía de su pareja, un médico asiático llamado Kim, y de Leonardo, el hijo de una antigua amiga de la infancia, Poli, que muere en una situación trágica y no menos espectacular : un asalto armado a una instalación militar ubicada en el «Dock» de Buenos Aires, un lugar impreciso cercano al puerto de Buenos Aires ${ }^{25}$. La «Lugarteniente Poli ${ }^{26}$ participa activamente en este ataque y muere en él. Días después, Margot, una vecina de Poli, contacta a la antigua amiga para que se haga cargo temporalmente de Leo. Como nada hay más definitivo que lo temporal, la custodia se perenniza. La responsabilidad maternal de la narradora nace en la costa uruguaya. Un pequeñísimo núcleo familiar se va consolidando en la vida cotidiana que se desarrolla en la casa materna de la localidad balnearia de Solís, departamento de Maldonado ( « la casa de Solís era la vieja casa familiar, el sueño de los Behn ») ${ }^{27}$. La violencia política y el sol plúmbeo de los primeros días de enero quedan del otro lado del Plata. El oriente ofrece refugio, calma, aire, energía vital a estos prófugos afectivos. Comenta la narradora :

[...] buscábamos el este, fugitivos que finalmente se acercan a su escondite.

El saber médico de Kim también atribuía nuestro apetito al mar, cuya mera cercanía (en especial, decía, el viento proveniente del mar) estimulaba una reacción saludable en todo el organismo.

Aún así, no registrábamos un aumento de la energía, sino todo lo contrario, un cansancio físico sorprendente junto a un estado emocional caracterizado por la falta completa de iniciativa. Cualquiera habría dicho que estábamos convalecientes. Kim me pedía que dejara de calificar tanto las cosas y me abandonara al vaivén adormecedor del tiempo. Lo que tanto nos cansaba, sostenía, era el imperio absoluto del tiempo.

En realidad, es todo lo que vinimos a hacer, argumenta Kim, matar el tiempo. Permitir que el tiempo nos invada, dejarnos atravesar por el tiempo. ${ }^{28}$

La misma ciudad de Montevideo parece anacrónicamente detenida en una suerte de pasado señorial. En el primer capítulo de la segunda parte, antes de instalarse en la ciudad balnearia, los personajes pasan por el centro de la capital uruguaya, una ciudad que encuentran agradablemente pueblerina. Los primeros párrafos del capítulo se detienen en su descripción :

Montevideo. Llegamos al centro de la ciudad cerca de las cuatro de la tarde. Las avenidas, con sus prolijos árboles a ambos lados del asfalto, tenían el bullicio de los pueblos, gentil e incluso tranquilizador, pese a estar en medio de una gran ciudad. Nunca la había visto así, obsoleta y distinguida, con el oropel aún brillante -sólo el oropel- de las glorias pasadas. La atmósfera, incluso el tránsito asordinado de los bulevares, tranquilizaba nuestros sentidos con su pereza de ciudad estancada. ${ }^{29}$ 
19 política no es el único eje vertebrador de la historia. No se cruza el Río para huir de la
dictadura y alcanzar la libertad, como lo hacían los románticos de la generación del 37. Tampoco el cruce se debe a razones estrictamente caseras (como sí lo hace uno de los personajes de Chejfec, y no puede hacerlo el otro) ${ }^{30}$. En El Dock, el cruce al Uruguay comporta la revelación de la vida familiar. Por medio de una operación metonímica y tipográfica el propio texto así lo destaca cuando Leonardo recupera el dinero que su madre tenía escondido en el departamento porteño en donde vivían, más precisamente, en la biblioteca, «detrás de la hilera de libros de aventuras " ${ }^{31}$. Ése es el dinero que les permite viajar a Solís. «Dijo que sabía exactamente dónde estaba el lugar de la plata. »", dice la narradora. La aventura de los tres personajes en las playas uruguayas consistirá en darle un sentido a la vida cotidiana y en encontrar un lugar, su lugar, en el Plata.

El cruce es sin dudas el núcleo ideológico primordial de la tercera novela de Martín Kohan, Los cautivos. El exilio de Echeverría ${ }^{33}$, un cruce que es tanto figura simbólica como estrategia textual puesto que en esta novela se realizan también desplazamientos de naturaleza discursiva. La idea de cruce guía no sólo los desplazamientos espaciales de los protagonistas de la historia, sino también, las operaciones literarias puestas en juego: regionalismo narrativo, narración romántica de trasfondo histórico, humor irónico, detenimiento descriptivo minucioso, fluidez narrativa provocada por el diálogo. ${ }^{34} \mathrm{El} \mathrm{texto,} \mathrm{organizado} \mathrm{en} \mathrm{dos} \mathrm{partes} \mathrm{(«Tierra} \mathrm{adentro} \mathrm{»} \mathrm{de} \mathrm{catorce} \mathrm{capítulos} \mathrm{y}$ "El destierro ", con diez capítulos) y un epílogo, es un todo heterogéneo cruzado por registros poéticos y tradiciones literarias. Desde el imaginario regionalista como tradición literaria que sostiene el universo literario de la primera parte hasta el relato de la travesía o cruce al Uruguay emprendido, separadamente, por dos de los protagonistas (Echeverría, Luciana) por razones ideológicas y también amorosas, la novela se construye en torno a un motivo sesgado: la oculta presencia de Esteban Echeverría en la estancia de Los Talas (1839-1840), y relata las miradas cruzadas entre el intelectual recluido en el casco de la estancia y dos gauchos, Gorostiaga y Tolosa, que desde la llanura auscultan su presencia secreta. Una mujer reúne ambos espacios, Luciana, discípula y amante de Echeverría. «El destierro» es la historia del desencuentro de Luciana y de Echeverría en Uruguay (en las ciudades de Colonia y de Montevideo). Luciana llega a Colonia del Uruguay, creyendo que allí encontraría a su enamorado, pero una ex amante local de Echeverría, Estela, le informa que el poeta había partido a Montevideo. Y agrega un dato falso : Echeverría partió acompañado por una joven de la alta sociedad porteña. Desalentada por la mentira, Luciana decide interrumpir su búsqueda y quedarse en Colonia. La Banda Oriental es en Los cautivos un espacio de fuga ${ }^{35}$, de desencuentro, de transitoria protección. Como en una visión caleidoscópica de espacios en fuga, el cuarto de Estela es a la ciudad de Colonia del Sacramento lo que Colonia es a Montevideo, y por extensión, lo que el Uruguay es al exilio para un argentino : un afuera intermedio, provisorio y cercano que no adquiere el peso existencial del exilio. Es en cambio destierro, entendido como negación del espacio propio, distancia vital, lugar de tránsito ( Colonia no fue más que un punto intermedio en el que [Echeverría] se detuvo transitoriamente ») ${ }^{36}$, de espera («Cada cual espera

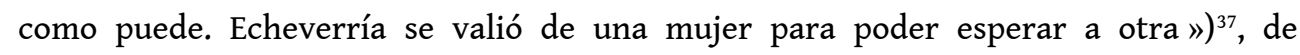
frustración amorosa ( Se fue con una damita elegante, una niña bien muy de Buenos Aires $»)^{38}$. Inevitablemente el cruce del río se carga de connotaciones políticas provenientes del registro literario argentino: Luciana se suma al cruce del río 
organizado por Daniel Bello, el noble opositor unitario primo de Amalia. El cruce del Río entraña un cruce de ficciones que imaginan la otra orilla como un estar políticamente del otro lado ( « [Luciana] dijo que viajaba a Colonia a encontrarse con un hombre que había prometido esperarla allí. Daniel Bello aceptó llevarla cuando supo que ese hombre era Esteban Echeverría. ») ${ }^{39}$. Del campo abierto y de la casa protectora de Los Talas de la primera parte de la novela se pasa progresivamente a un espacio menor, más íntimo, en la segunda: el cuarto de un prostíbulo, y finalmente en el epílogo, la tumba. El destino final del poeta y sus dos amantes es el de la desaparición definitiva. Ellas, aisladas en el cementerio de Colonia: Estela por prostituta, Luciana seguramente por suicida ${ }^{40}$. El cuerpo de Echeverría en cambio, extraviado, desaparecido, literal y simbólicamente des-terrado, durante el sitio de la ciudad de Montevideo por el General Oribe ${ }^{41}$.

Boomerang ${ }^{42}$, primera novela del escritor Elvio Gandolfo, publicada en 1993, cuenta la historia de una escapada al Uruguay. Los personajes principales son Iván Garré y su amiga uruguaya Paula. Garré trabaja en un banco porteño, es un "samurai de la informática » que realiza una malversación de fondos (un «looping», título del primer capítulo) por unos cincuenta y tres mil dólares y comprende que debe «rajar $»^{43} \mathrm{al}$ Uruguay. Ambientada en los años noventa, la novela da cuenta de la situación políticosocial en uno y otro lado del Plata : el menemismo argentino y el lacallismo uruguayo. La idea no es la de retirarse totalmente, sino la de ausentarse para trabajar mejor desde el otro lado (Colonia, Montevideo, Punta del Este), sin ser descubierto. Un fin de semana largo del mes de mayo, Garré, una suerte de yuppie porteño amante del rock anglosajón y de los chicles de mentol, saltará el charco para pasar en el lado oriental un desenfrenado fin de semana. En el otro lado conocerá a Paula, una uruguaya muy atractiva con quien Garré iniciará una extraña relación : paseará por bares céntricos, shoppings, casinos y discotecas gastando el dinero robado. Si bien el Uruguay « es otro país $»^{44}$, es también « casi una provincia nuestra $\star^{45}$, y lo que Garré necesitaba, dice el narrador, era " un sitio intermedio desde donde seguir moviéndose en caso necesario " 46. Y agrega que la idea de viajar al Uruguay "surgió con el peso sordo de lo obvio» puesto que « desde allí podía saltar a otro país si confirmaba que lo habían descubierto, o regresar con rapidez si todo quedaba en nada $»^{47}$. Más que brindar seguridad, la orilla oriental se presenta como un lugar estratégico por su posición intermedia entre la posibilidad de retorno y la ventaja de una posible evasión definitiva. Es un lugar tranquilo donde "esperar hasta saber si debe volver o seguir huyendo $»^{48}$. Por su lentitud, el ferry que partía de Buenos Aires parecía "salido de otros tiempos »; una "fascinación hipnótica ${ }^{49}$ lo va ganando. Ya en el mostrador de Migraciones de la costa uruguaya " todo tenía un aire lento, detenido, ocioso », y los pasajeros se movían « con pereza $»^{50}$. Hasta la identidad se suspende : Paula no se llama Paula, e Iván Garré puede ser Fernando Lamas. Montevideo tiene "cierto aire», cierto "ritmo sereno $»^{51}$, " parece Buenos Aires en los años cuarenta " ${ }^{52}$. "El tirón del deseo $"^{53}$ lo enlaza a Paula. Una vez terminado el largo fin de semana, Garré vuelve a Buenos Aires y retoma su vida cotidiana.

En 1997, Ricardo Piglia publica Plata quemada ${ }^{54}$. Nuevamente, un delito origina el cruce, la fuga al Uruguay. La expresión del cruce al Uruguay, en secreto, está insistentemente mencionada ${ }^{55}$. Se trata aquí de una versión más violenta del delito. La novela se basa en una historia real ocurrida entre Buenos Aires y Montevideo. Los hechos reales se desarrollan entre el 27 de septiembre y el 6 de noviembre de 1965. Una banda de asaltantes atraca un banco en San Fernando (provincia de Buenos Aires), en la huida 
deciden traicionar a sus cómplices y escaparse al Uruguay con el dinero robado. Contra los esquematismos identitarios y las fronteras sociales, las peligrosidades que el texto propone están concentradas en el dinero, la sexualidad, la droga y la resistencia. En la resistencia épica de los malhechores que se resignan a "morir pero matando " $^{56}$, resuena la sexualidad como un contra-poder, y también, la intransigencia política de montoneros y de tacuaras :

'Los que huyeron (ha dicho off the record el comisario Silva) son sujetos peligrosos, antisociales, homosexuales y drogadictos', y agregó el jefe de policía 'no son tacuaras ni peronistas de la resistencia, son delincuentes comunes, psicópatas y asesinos con frondosos prontuarios'.

Estos señores son psicópatas, homosexuales. -Miró a Renzi- Casos clínicos, basura humana.

Son fríos, no tienen piedad. [...] Son un ejército en miniatura. La adrenalina los ayuda a superar el terror. Están pichicateados, son máquinas de matar. ${ }^{57}$

En el espectáculo de la resistencia final que se vive en Montevideo hay cierta ferocidad asociable con el canibalismo : «son unos bestias, dijeron los periodistas [...] -Quemar dinero inocente es un acto de canibalismo ", concluye el periodista televisivo Jorge Foister ${ }^{58}$. El delito se entrelaza con la violencia de lo contrafáctico, y también, con la violencia primitiva y primaria anteriormente mencionada que parecería ser un rasgo mítico distintivo de la región. Ni lugar intermedio, ni espacio de salvación política o descanso doméstico, en esta novela las dos orillas disuelven sus diferencias y se reúnen en la práctica de la « violencia ilegal $»^{59} \mathrm{y}$ desenfrenada. La pesquisa policial coordinada entre ambos lados del Plata termina con los asaltantes, un accionar que preludia lo que será el dispositivo represivo de la década siguiente.

\section{El lugar del como si}

Diferentes, iguales o parecidas, las dos orillas son siempre dispositivos discursivos. Así lo analizan Sergio Chejfec, Graciela Silvestre y Gerardo Caetano en tres notas periodísticas que, desde perspectivas diferentes (literaria Chejfec, urbanística Silvestre, sociológica Caetano), reflexionan sobre las representaciones acerca del otro lado. Estas notas sintetizan cada una a su manera elementos que la literatura ficcionaliza y que los artículos de este volumen retoman en sus análisis. Las resumiremos a continuación, antes de pasar a la presentación de nuestros artículos.

Localización ideológica, locus metafórico, descanso simbólico, refugio político (cuando no bancario), arcadia rioplatense, paraíso sociológico, remanso cultural, experimento imaginario vaciado de frustraciones políticas e históricas, fantasma obediente declinado en modo subjuntivo (la costa uruguaya es como si fuera... la costa argentina), son todas las conceptualizaciones que de la costa montevideana, y por extensión del Uruguay, ofrece Sergio Chejfec en su esclarecedor artículo «La parte por el todo. Alegato oriental $\gg(2009)^{60}$.

26 En « Por qué los porteños soñamos con Montevideo » $(2004)^{61}$, Graciela Silvestre analiza los preceptos de la modernización en la configuración urbana de una y otra ciudad del Plata y la representación simbólica que la organización de cada espacio ofrece a sus ciudadanos. Según Silvestre, Montevideo, a diferencia de la Reina del Plata, supo preservar « una gestión igualitaria del espacio público y de las bellezas naturales » y postula que esta organización democrática de la circulación ciudadana alimenta el 
imaginario porteño. Precisa que «desde el período rosista hasta la década de los noventa ", la ciudad de Montevideo es representada « como un lugar donde los ideales democráticos parecen resistir con mayor firmeza ». En su argumentación, Silvestre sostiene que el mito rioplatense de Montevideo se caracteriza por su diferencia respecto de otros mitos urbanos latinoamericanos en los cuales « la nostalgia de una edad de oro conduce a la Colonia, a las culturas precolombinas o a la pureza natural ». Montevideo es una "arcadia política", es "la nostalgia de un breve momento de expansión moderna e igualitaria ». Considera que tres son los períodos esenciales de constitución de este mito montevideano, tres momentos que están directamente asociados a la vida política argentina, a tres coyunturas que tienen que ver con el exilio. Se refiere en primer lugar al rosismo (periodo conocido como la primera tiranía); en segundo lugar, al peronismo (denominado también como la segunda tiranía); y finalmente, al periodo de retorno a la orilla porteña iniciado hacia mediados de los años 80, luego de la caída de la dictadura en Argentina. Si la democracia neoliberal de la década de los 90, prefirió la sobriedad vanguardista en la estructura edilicia de Buenos Aires, en esos mismos años, Montevideo preservó, según Silvestre, una repartición equitativa del espacio público en el cual vibró siempre el ideal democrático de la igualdad cívica ${ }^{62}$. A esta interrupción del paisaje urbano y desaparición de ciertos espacios públicos porteños integrados al Río hace referencia el escritor Carlos María Domínguez, en la entrevista que se le hizo para el presente número, cuando recuerda los buenos momentos juveniles pasados en la costanera norte porteña, antes de la puesta en marcha del plan de autopistas urbanas iniciada en 1978. En La canción de las ciudades $^{63}$, Matilde Sánchez va en el mismo sentido cuando su narradora expresa que: «Una buena política forestal como la uruguaya nos habría permitido disfrutar de nuestra costa. ».

En opinión de Gerardo Caetano, en su artículo «Uruguay y su transición de imaginarios" (2005) $)^{64}$, la esfera uruguaya de lo público es una operación de «sacralización civil de ciertos rasgos de la vida comunitaria al difundir rituales públicos, liturgias cívicas y simbologías populares, con el objetivo inocultable de reforzar la identidad y el orden nacionales ». Esta sacralización está sostenida desde los manuales escolares y los libros de Historia. Esta suerte de religión de lo civil, de «catecismo fundacional» del nacionalismo popular es, según Caetano, uno de los pilares del discurso de identidad uruguayo. La voluntad de afirmación nacional se afirma también en otros tópicos identitarios como: la representación de un cosmopolitismo eurocéntrico y noroccidental acompañado de un rechazo de lo autóctono; las relaciones conflictivas con Argentina y Brasil desde la época de la Colonia (el federalismo artiguista contrapuesto al centralismo porteño, las repetidas invasiones: portuguesa primero, brasileña luego); los peligros que debió afrontar el Uruguay para afirmarse frente a las políticas expansionistas del gigantismo vecino ; y finalmente, la convicción de ser una sociedad más cohesionada y estable que la argentina y la brasileña. Esta autopercepción nacionalista, que dio lugar al tópico del Uruguay como la "Suiza de América », comienza a debilitarse, según Caetano, hacia mediados del siglo XX.

Todo lo expuesto parece configurar el lado oriental del Plata como un espacio transitivo, un imaginario declinado según las experiencias del exilio, la libertad, la fuga, el escape, la recomposición personal, la proyección política, el refugio, el placer de la pereza. Lo oriental rioplatense es espacio intermedio, estado de suspensión temporal, tiempo estancado, respiro, aire. Y el Río que une ambas orillas está literaria e 
históricamente cargado de pesar, de congoja, de muerte. De carne degradada. Los siete artículos que integran el presente volumen abordan de manera sesgada a veces, puntual otras, estas caracterizaciones. Metodológicamente lo hacen de tres maneras : estableciendo diálogos sesgados entre las literaturas de una y otra orilla, creando productivos territorios literarios entre autores, y desmitificando imaginarios representacionales.

Dos son los artículos que leen de manera oblicua el diálogo literario, tanto productivo como imaginario, entre ambas orillas. El primero de ellos, el trabajo de Ana María Amar Sánchez (Universidad de Irvine), « Narrar al sesgo : diálogos entre dos orillas en torno al horror», propone una lectura cruzada en la producción de seis escritores rioplatenses: los argentinos Jorge Luis Borges, Julio Cortázar, Juan Sasturain, y los uruguayos Omar Prego Gadea, Elvio Gandolfo, Mario Delgado Aparaín. Siete textos son evocados en su análisis : «Deutsches réquiem » (El Aleph, 1949), "Graffiti » (Queremos tanto a Glenda, 1980), "Segunda vez» (Alguien que anda por ahí, 1977), "Función nocturna » (Sólo para exiliados, 1987), «San Jodéte, apóstol de la desgracia » (Zenitram, 1996), La balada de Johnny Sosa (2000) y Alivio de luto (1999). Las figuras de Juan Carlos Onetti (Los adioses) y de Héctor Oesterheld (El Eternauta) centellean en estos cruces literarios que ponen en juego los límites de la representación y las maneras rioplatenses de representar el mal y el horror. Contra la tentación de la identificación personal y del pretender decirlo todo, estos textos instauran, según Amar Sánchez, una poética de la reticencia que hace de la omisión, el desvío y el distanciamiento brechtiano no sólo una propuesta estética, sino también una toma ética de partido.

El segundo artículo es el de Graciela Villanueva (Universidad de Créteil), quien estudia la presencia del Uruguay en la obra de Jorge Luis Borges. En « El Uruguay de Borges : un justo vaivén de la aproximación y de la distancia", Villanueva recorre transversalmente la obra del escritor argentino rescatando minuciosamente las referencias al Uruguay y a su gente que, con cierta frecuencia, aparecen en sus ensayos, en su poesía y en sus cuentos. En algunos de los textos estas referencias al país vecino son centrales, en otros textos son apenas puntuales y, más a menudo, las menciones son sesgadas. Villanueva analiza agudamente los matices de estas referencias. Partiendo de la base, ya examinada por la crítica borgeana, de que el Uruguay es imaginado en la obra del autor como un lugar de refugio de los argentinos frente a la barbarie, se desbroza en el artículo esta representación general. Para ello Villanueva vuelve sobre textos clave como : la Autobiografía (1970) de Borges, para releer su genealogía uruguaya y los valores que el escritor concede a estos orígenes; Inquisiciones (1925, «Queja de un criollo») ; El tamaño de mi esperanza (1926, « La tierra cárdena »); Para las seis cuerdas (1965, « Milonga para los orientales »); El libro de arena (1975, «El otro », "Avelino Arredondo », «El congreso ») ; Luna de enfrente (1925, « Montevideo »); Ficciones (1944, " Tlön, Uqbar, Orbis Tertius ", "Funes el memorioso ", « La forma de la espada ») y El Aleph (1949, «El muerto », «La otra muerte »). Desde el elogio de la bravura oriental y de los valores criollistas compartidos en ambos lados del Plata, consistentes en la desesperanza, el desgano, la sencillez, el apego a lo conocido, además de una incontestable desconfianza por lo urbano y lo moderno; pasando por el marcado interés que en Borges despierta la poesía uruguaya y sus escritores (Pedro Leandro Ipuche, Fernán Silva Valdés, Julio Herrera y Reissig), interés expuesto en sus ensayos de Inquisiciones (1925) y en El tamaño de mi esperanza (1926); hasta la construcción " entreverada y confusa", según Villanueva, de una epopeya histórica rioplatense consistente en la recreación a lo largo de toda su obra de la constelación de batallas 
ocurridas durante las guerras civiles en el siglo XIX, de los escenarios políticos, de sus protagonistas (principales y secundarios) y de sus bandos en ambos lados del Plata, el imaginario rioplatense de Borges va construyendo en torno al paso lento del tiempo un sentido compartido tanto temporal como espacialmente.

Tres son los artículos que analizan la literatura rioplatense como construcción de un territorio literario sin fronteras. En « La disolución de las fronteras. Notas para pensar la "otra orilla" en la obra de Marosa di Giorgio", Adriana Canseco (Universidad Nacional de Córdoba - CONICET) estudia la obra de la escritora uruguaya Marosa di Giorgio (1926-2004). Valiéndose de la noción de territorio poético y de frontera, la crítica argentina postula que di Giorgio erige en su obra un espacio movedizo tanto en lo formal como en lo temático, que repercutió en la producción crítica que, desde los años 90 principalmente, en Argentina, se viene haciendo de su obra. Su poética trasciende las delimitaciones nacionales. Según Canseco, el desborde genérico y las escasas referencias culturales y temporales contribuyen a la creación de un imaginario poético rioplatense que trasciende lo nacional. Canseco recorre la historia de las publicaciones marosianas dentro y fuera de Uruguay y sostiene que la recepción de esta obra pone en evidencia un cruce de voces críticas provenientes de ambas orillas. La publicación que, en los últimos veinte años, ciertas editoriales argentinas vienen haciendo de su producción, ha provocado también la circulación de su obra a escala latinoamericana, fenómeno que tiene su marco más general en la expansión que en la década de los 90 tuvo, a escala regional, el neobarroco. El Neobarroco (o barroco moderno, o neobarroso rioplatense según Néstor Perlongher) ${ }^{65}$ supo restaurar un diálogo regional que había sido fluido durante el Modernismo y que se interrumpió durante el Vanguardismo. Dicho transvase poético comportó también, según Adriana Canseco, un corrimiento transfronterizo en la crítica rioplatense.

32 Las reflexiones de Carina Blixen (Universidad de Lille) en su estudio de la obra de Carlos Liscano, "Carlos Liscano, Jorge Luis Borges y Macedonio Fernández: un triángulo de dos orillas", exponen las relaciones literarias entre los tres escritores. Blixen sostiene que Borges ("Pierre Menard, autor del Quijote») y Macedonio Fernández (Museo de la novela de la eterna) se vuelven modelos explícitos en los últimos textos de Liscano: Vida del cuervo blanco (2009), Oficio de ventriloquia 2 (2011) y «El trabajo de recontar» (2012) a través de la exploración del modelo de escritura del «narrar pensando o de pensar narrando». La manera en que la narración y el pensamiento se complementan integrándose da lugar en la escritura de Liscano a una prosa poética hecha de reiteraciones. Blixen asocia este mecanismo escriturario a la modalidad «salteada » de lectura y de escritura que Liscano adquirió durante los años pasados en la cárcel (en el penal Libertad, de 1972 a 1985), periodo en el cual leyó las obras de la biblioteca del penal (entre las cuales figuran Borges y Macedonio Fernández) y los libros que los familiares llevaban a los presos. Manuscritos de la cárcel (2010) reúne casi toda la obra de Liscano escrita en prisión. En estas condiciones de atención interrumpida crea mentalmente su primera novela, La mansión del tirano (1992). «Apuntes de literatura y política » (sin fecha) reúne sus transcripciones de los autores leídos en la cárcel. Blixen sostiene que Liscano empezó a escribir copiando, transcribiendo, reescribiendo, como un proceso interior que implica reelaborarse en la repetición y la diferencia. La imaginación, los recuerdos, la reescritura de obras propias y ajenas, las referencias librescas, su intimidad, la recuperación de expresiones de la 
cultura popular uruguaya y de la argentina, el acervo literario rioplatense (Borges, Macedonio) son los materiales transterritoriales de su (re-)escritura.

Partiendo del imperativo onettiano de que inventar es siempre crear un lugar alternativo, Oscar Brando (Universidad de Lille) analiza en su artículo «De Arlt a Onetti : camas desde un peso » las figuraciones a través de las cuales Montevideo y Buenos Aires son representadas en las literaturas de Roberto Arlt y de Juan Carlos Onetti. Brando parte de unas declaraciones de Onetti acerca de ambas ciudades en relación con la ciudad inventada de Santa María. En estas declaraciones, Onetti considera Montevideo como una "ciudad fantasma » y Buenos Aires como una ciudad ajena, puesto que para Onetti, Buenos Aires ya pertenecía ficcionalmente a Roberto Arlt. Desde la hipótesis de la necesidad de crear un espacio alternativo para la ensoñación, Oscar Brando recorre los tópicos ciudadanos que circulan en las literaturas de ambas orillas. Analiza principalmente estos tópicos en las literaturas de Juan Carlos Onetti (de quien retoma El pozo, 1939 ; La vida breve, 1950 ; « Avenida de Mayo-DiagonalAvenida de Mayo », 1933) y de Roberto Arlt (El juguete rabioso, 1926 ; Los siete locos, 1929 ; Los lanzallamas, 1931; El amor brujo, 1932; Aguafuertes porteñas, 1933). La angustia, la soledad, la incomunicación, el fracaso, el cosmopolitismo, la noche, la sordidez son leídos en (o desde) un espacio común muy particular : las habitaciones por un peso. Estas representaciones estarían, según Brando, vaciadas del misticismo borgeano y estarían también alejadas de las geografías móviles o de la a-territorialidad de la escritura de la memoria (Felisberto Hernández). El territorio literario compartido esboza el contorno de un existencialismo rioplatense.

Finalmente, dos trabajos se interesan por la deconstrucción que la literatura rioplatense más reciente viene haciendo de la lectura mitificada de los valores culturales uruguayos y de cuestiones relacionadas con la identidad nacional. Ilse Logie (Universidad de Gante) estudia en su artículo «Geografías ficcionales: El Uruguay de Copi » la obra del dramaturgo argentino Raúl Damonte Botana, mucho más conocido como Copi. Logie centra su análisis en la nouvelle El Uruguayo (1972), texto en el cual el dramaturgo argentino coloca al Uruguay en las antípodas de la dulce y mítica territorialidad imaginada. En su opinión, la estética trans- del iconoclasta Copi, la mirada apocalíptica de la mítica estabilidad uruguaya, la presentación grotesca, burlesca y exagerada del mito del sosiego oriental hacen de El Uruguayo un texto precursor en materia de desrealización narrativa en el Río de la Plata. ${ }^{66} \mathrm{El}$ análisis de este rechazo de toda construcción territorial y de todo sentido de pertenencia cultural evoca también otras obras del autor como las novelas Le bal des folles (1977), La cité des rats (1979), Virginia Woolf a encore frappé (1983), L'internationale argentine (1988), y la obra de teatro Eva Perón (1970). Según Logie, Copi realiza una lectura desviada de lo uruguayo, pero también hace de lo oriental (Uruguay, Francia) un espacio necesario de desvío para poder hablar de lo argentino. Copi desvía los cánones interpretativos en torno a la dulce tierra oriental, y a la vez, o por lo mismo, hace de ese espacio desviado el lugar desde donde poder operar con mayor eficacia estética el contrarrelato de lo nacional argentino, el sacrilegio de lo propio. El trabajo de Logie no olvida el rescate que la literatura y la crítica argentinas vienen realizando en las últimas décadas (desde Copi de César Aira, 1991) de su díscola figura de autor como de su provocadora propuesta estética. Extranjero en todas partes, Copi, el apátrida, supera según Logie no solamente las fronteras geográficas (Argentina, Uruguay, Francia), sino también los sistemas literarios nacionales. 
El artículo de Jesús Montoya Juárez (Universidad de Murcia), « Multiterritorialidad imaginada en la última narrativa uruguaya : a propósito de La vista desde el puente de Ramiro Sanchiz ", retoma la noción de territorio desde la idea de lo múltiple. Montoya Juárez considera que la multiterritorialidad es una noción cultural clave en nuestro presente, puesto que caracteriza las identidades sujetas a diferentes procesos de transnacionalización. Según Montoya Juárez, la ficción contemporánea uruguaya se inclina en buena parte hacia un proceso de representación de la multiterritorialidad (imaginada o motivada por la realidad) antes que de desterritorialización. En tal sentido, la novela de Ramiro Sanchiz, La vista desde el puente (2011), cuestiona los límites del territorio uruguayo al imaginar que dichos límites trascienden el consagrado perímetro de la Banda Oriental y que se extienden hasta las provincias de Río Grande del Sur en el Brasil, y de Corrientes y Entre Ríos en la Agentina. El Uruguay no es entrevisto como un territorio oriental y anexo de la República Argentina. La novela pone en crisis la narrativa identitaria uruguaya de dos maneras : en primer lugar, al convocar la noción desacralizadora de multiterritorialidad, y en segundo lugar, al proponer una interpretación alternativa de la historia nacional uruguaya que desmonta la imagen de homogeneidad nacional. La mirada desde el puente rescata el conflicto intercultural, re-etniza la identidad y la lectura de la historia, desmitifica héroes nacionales, opaca la versión dominante del Uruguay como "pueblo trasplantado", socialmente homogéneo, y regionalmente presentado como la "Suiza de América ». Según Montoya Juárez, el proceso de transnacionalización del imaginario uruguayo se debe a la intensificación de los flujos migratorios que el país viene sufriendo desde los primeros años del presente siglo. El tono irrisorio y pesadillesco con el que se deconstruye la narrativa de identidad uruguaya y se construye la historia contrafáctica que ofrece la novela reposa en el personaje principal, el escritor Federico Stahl, quien luego del suicidio de su padre se sumerge en la investigación histórica que él llevaba adelante. La reflexión de Montoya Juárez en torno a la reconstrucción de este nuevo imaginario colectivo al que la novela de Sanchiz invita, se completa y complementa con un interesante y actualizado panorama de la literatura uruguaya reciente: sus vertientes, sus jóvenes autores y la creación de nuevas editoriales, sin olvidar mencionar las nuevas políticas culturales que, desde los últimos cinco años, vienen poniéndose en práctica.

Problematizar la noción de literatura rioplatense, establecer el diálogo entre textos literarios contemporáneos a la luz del cruce de categorías como las de identidad, representación, nación, cultura, frontera, territorio, sin olvidar los diversos procesos a través de los cuales la Historia debe leerse : los estéticos, pero también los políticos, los culturales, los sociales, los económicos han sido los propósitos principales del presente volumen. Las reflexiones de los seis autores encuestados que integran este número complementan y refuerzan los aspectos señalados.

\section{NOTAS}

1. J.J. Saer, El entenado [1983], Buenos Aires, Folios Ediciones, 1983, p. 35. 
2. R. Díaz de Guzmán, Argentina manuscrita, o Anales del descubrimiento, población y conquista de las Provincias del Río de la Plata [1835], Buenos Aires, Estrada, 1943, p. 113.

3. U. Schmidl, Derrotero y viaje a España y las Indias, traducción del alemán, según el manuscrito de Stuttgart, por Edmundo Wernicke, Buenos Aires, Espasa-Calpe, 1944. Colección de viajes en dos tomos, escritos de regreso a su Bavaria natal, y publicados por primera vez en 1567. El episodio se encuentra en el capítulo IX. La cita fue extraída de : S. Calero y E. Folino, Cronistas de Indias. Antología, Buenos Aires, Ediciones Colihue, 1982, p. 153. Se conoce el nombre del español al cual Schmidl se refiere. Se trata de Diego González Baitos, protagonista además del cuento de M.Mujica Lainez, «El hambre» (Misteriosa Buenos Aires [1951], Buenos Aires, Editorial Sudamericana, 1993, p. 9-16. Mujica Lainez fecha el suceso en 1536.

4. J.L. Borges, "Fundación mítica de Buenos Aires ", Cuaderno San Martín, en Obras Completas 1923-1972, Buenos Aires, Emecé Editores, 1974, p. 81.

5. J.J. Saer, El entenado, op. cit., p. 43

6. Las precisiones históricas están ausentes en el texto, pero son inferibles. Se trataría de la expedición de Juan Díaz de Solís (1516), descubridor del Río de la Plata, al que bautizó como Mar Dulce por su gran anchura y la baja salinidad de sus aguas. La expedición remonta el río hasta el delta del río Paraná, y cuando Solís y algunos de sus hombres bajan a tierra, en la costa oriental, son atacados por aborígenes que les dan muerte. Sus cuerpos fueron asados y devorados por los aborígenes. Se cuenta que el único sobreviviente de la matanza fue el grumete Francisco del Puerto, quien vivió con los indígenas (aparentemente los charrúas) hasta que fue rescatado por la expedición de Sebastián Gaboto, diez años después, en 1527, en el puerto de Colonia. Ningún testimonio escrito queda del grumete histórico. Al respecto: M.C. Pons, «El entenado: la representación histórica de una otredad ausente ", en Memorias del olvido. La novela histórica de fines del siglo XX, México, Siglo XXI editores, 1996, p. 212-253.

7. J.J. Saer, El entenado, op.cit., p. 24.

8. J.J.Saer, El río sin orillas. Tratado imaginario, Buenos Aires, Seix Barral, 2011, p.29-30.

9. J. Mármol, Amalia, Buenos Aires, Capítulo, 2 tomos, 1984.

10. Ibid., « En Montevideo », Tercera parte, capítulo 1, p. 272.

11. Ibid., p. 7-8.

12. W.H. Hudson, La tierra purpúrea. Allá lejos y hace tiempo [1885], Caracas, Biblioteca Ayacucho, 1980, 615 p. Al respecto puede consultarse también William Henry Hudson y La tierra purpúrea: reflexiones desde Montevideo, de Beatriz Vegh y Jean-Philippe Barnabé (coordinadores), Montevideo, Universidad de la República, Facultad de Humanidades y Ciencias de la Educación, Departamento de Letras Modernas, Linardi y Risso, 2005, 230 p. Actas del Coloquio Narrando los márgenes: Hudson y The purple land celebrado en Montevideo del 23 al 25 de julio de 2004.

13. Ibid., p. 181.

14. J.L.Borges, « Nota a La tierra purpúrea » [La Nación, 3 de agosto de 1941].

15. M.Kohan se refiere a esta problemática del cruce al Uruguay en su artículo « Partir sin partir del todo ", en Revista Todavía, $\mathrm{n}^{\circ}$ 1, mayo 2002, p. 30-31. Reseña estas novelas y omite su inclusión en la serie. Este artículo inspiró nuestra reflexión. Consultable en http:// www.revistatodavia.com.ar/notas/kohan/frame_kohan1.htm. Última consulta : 10/12/2012.

16. S.Chejfec, El aire, Buenos Aires, Alfaguara, 1992.

17. « Así, la distracción había pasado a ser para él una forma del tedio, y la lentitud adquiría la categoría de indolencia. ", Ibid., p. 145.

18. Ibid., p. 150.

19. Ibid., p. 142.

20. Ibid., p. 146.

21. Ibid., p. 39, p. 125.

22. Ibid., p. 164.

Cuadernos LIRICO, 8 | 2013 
23. Ibid., p. 93. A.Oeyen analiza el motivo de la barbarie en esta novela en su artículo « La vuelta de la barbarie en El aire de Sergio Chejfec ", en Lieux et figures de la barbarie, CECILLE - EA 4074, Université Lille 3, 2006-2008. Consultable en http://evenements.univ-lille3.fr/colloquebarbarie2008/seminaires/Annelies-Oeyen.pdf. Consultado el 15/12/2012. Acerca de la representación de la ciudad puede también consultarse el artículo de C. Komi, «El aire y Boca de lobo de Sergio Chejfec : una poética de la ausencia », en T.Orecchia-Havas (éd.), Les villes et la fin du XXe siècle en Amérique Latine: Littératures, cultures, représentations, Bern, Peter Lang, 2007, p. 383-394.

24. M.Sánchez, El Dock, Buenos Aires, Seix Barral, 1993.

25. Las imágenes del asalto armado al cuartel por los rebeldes que la narradora sigue por televisión remiten de manera implícita pero evidente al ataque y toma del cuartel de La Tablada, realizado por milicias populares pertenecientes a diversos grupos armados de izquierda, el 23 y 24 de enero de 1989.

26. M. Sánchez, El Dock, op.cit., p. 84.

27. Ibid., p. 103.

28. Ibid., p. 123, 135, 136 respectivamente.

29. Ibid., p. 121.

30. Acerca de la novela de Sánchez dice Kohan muy perspicazmente que « Ni cruce político ni cruce doméstico : en El Dock, el cruce al Uruguay es un cruce de lo político a lo doméstico.». En « Partir sin partir del todo », op.cit.

31. M. Sánchez, El Dock, op.cit., p. 113.

32. Idem. Destacado en el original.

33. M. Kohan, Los cautivos. El exilio de Echeverría, Buenos Aires, Editorial Sudamericana, 2000.

34. Hemos analizado estos desplazamientos así como la constitución del espacio dramático de la novela en « El cruce al Uruguay : desplazamientos narrativos y espaciales en Los cautivos. El exilio de Echeverría, de Martín Kohan ", Confluencia. Revista Hispánica de Cultura y Literatura, Fall 2006, vol. $22, \mathrm{n}^{\circ} 1$, p. 102-110.

35. M. Kohan, Los cautivos. El exilio de Echeverría, op.cit., p. 134-136.

36. Ibid., p. 145.

37. Ibid., p. 144.

38. Ibid., p. 154.

39. Ibid., p. 139.

40. Ibid., p. 168-169.

41. Ibid., p. 170.

42. E. Gandolfo, Boomerang, Montevideo, Editorial HUM, 1993.

43. Ibid., p. 7-15.

44. Ibid., p. 18.

45. Ibid., p. 25.

46. Ibid., p. 15.

47. Ibid., p. 16.

48. Ibid., p. 25.

49. Idem.

50. Ibid., p. 27.

51. Ibid., p. 50.

52. Ibid., p. 65.

53. Ibid., p. 55.

54. R. Piglia, Plata quemada, Buenos Aires, Planeta, 1997.

55. Ibid., p. 62, 65, 82, 86.

56. Ibid., p. 214.

57. Ibid., p. 91 y p. 197 respectivamente. 
58. Ibid., p. 191.

59. Ibid., p. 246.

60. S. Chejfec, "La parte por el todo. Alegato oriental», en Diario de poesía, Buenos Aires, 01/01/2009. Consultable en http://parabolaanterior.wordpress.com/2009/01/01/la-parte-por-eltodo/ . Consultado el 22/11/2012.

61. G. Silvestre, «Por qué los porteños soñamos con Montevideo", en revista TodaVía, $n^{\circ} 9$, diciembre 2004. Consultable en http://www.revistatodavia.com.ar/todavia09/notas/silvestri/ txtsilvestri.html. Última consulta : 15/12/2012.

62. Más precisamente dice Silvestre: «Las políticas urbanas del Frente Amplio, que obtuvo la intendencia en 1989, reunieron las solicitaciones del presente con la preservación de este carácter físico que remitía a la igualdad física », una « felicidad democrática que la playa amplia y pública parece resumir.»

63. M. Sánchez, La canción de las ciudades, Buenos Aires, Planeta, 1999, p. 144.

64. G. Caetano, «Uruguay y su transición de imaginarios », revista Todavía, n 11, agosto de 2005. Consultable en http://www.revistatodavia.com.ar/todavia28/11.caetanonota.html. Consultado el 12/12/2012.

65. Dice Perlongher: "Yo hablaría de 'neobarroso' para la cosa rioplatense, porque constantemente está trabajando con una ilusión de profundidad que chapotea en el borde de un río. », en «El neobarroco rioplatense » (entrevista de Eduardo Milán), Papeles insumisos, edición de A. Cangi y R. Jiménez, Buenos Aires, Santiago Arcos, 2004, p. 285. Citado por Ana Porrúa en su artículo " "Cosas que se están hablando" : versiones sobre el neobarroco », en Boletín n 13-14 del Centro de Estudios de Teoría y Crítica Literaria, Diciembre 2007 - Abril 2008. Consultable en http://www.celarg.org/int/arch_publi/porrua13_14.pdf. Última consulta : 20/12/2012. Entrevista publicada por primera vez en el $n^{\circ} 134$ del diario Jaque, Montevideo, 3 de agosto de 1986, p. 4. Consultable en http://www.revistasolnegro.com/sol\%20negro/nestorpormilan.htm.

Última consulta : 20/12/2012. De Néstor Perlongher, ver también : « Neobarroco y neobarroso ", en Caribe trasplatino. Poesia neobarroca cubana e rioplatense, San Pablo, Iluminuras, 1991, p. 19-20.

66. El agudo análisis de Ilse Logie nos sugiere el recuerdo del polaco Witold Gombrowicz, quien en 1960, de paseo por la costa uruguaya, percibió el sosiego montevideano como un escozor insoportable. Entrevió o imaginó también su contracara : el letargo intelectual. Acerca de su visita a Montevideo escribió Gombrowicz en su Diario: "Paseo por una ciudad limpia, con balcones estrafalarios y gente apacible. Montevideo. Aquí todavía reina la antigua decencia erradicada ya de muchas otras regiones de América del Sur. Caras benévolas, vestidos que denotan bienestar, la playa a veinte minutos de autobús, ¡un paraíso ! ¿Y si me viniera a vivir aquí ? [...] ¿Quietud ? ¡Inquietud ! Me inquieta un poco la falta total de "escalofrío metafísico" en la capital uruguaya, donde ningún perro ha mordido jamás a nadie. » En Diario (1953-1969), Buenos Aires, Seix Barral, 2005. Sergio Chejfec, en el artículo mencionado, se refiere a este comentario de Gombrowicz y lo cita en parte.

\section{AUTOR}

\section{MARTA INÉS WALDEGARAY}

Université de Lorraine 